\title{
Analisis Ketersediaan Air DAS Sausu Untuk Kebutuhan Air Pada D.I. Sausu Bawah, Kabupaten Parigi Moutong
}

\author{
W. Andita ${ }^{a}$ dan S. Lipu ${ }^{\text {** }}$ \\ a Jurusan Teknik Sipil, Fakultas Teknik Universitas Tadulako, Palu \\ ${ }^{*}$ Corresponding author's e-mail: sancelipu@gmail.com
}

Received: 7 August 2020; revised: 25 August 2020; accepted: 27 August 2020

\begin{abstract}
This study aims to grasp and analyze the water availability in Sausu Watershed and the need of water in Lower Sausu Irrigation Scheme. The research begins with data collection and hydro-climatological analysis to determine whether the water is enough or not enough to be used during a hydrological period. To obtain the comparison between the needs and availability of water, a hydro-climatological analysis and calculation of water need are carried out. Methods that used namely the Penman Modification method and the F.J Mock method. Penman modification method is used to calculate monthly evapotranspiration (ETo) by taking into account climatological factors such as air temperature, wind speed, solar radiation and relative humidity. By applying the F.J.Mock method for calculating the water availability, the amount of water flow from the rain, characteristics of the drainage area and evapotranspiration can be calculated. Based on the results of data analysis for Sausu watershed area of $568.64 \mathrm{~km}^{2}$, it shows that the average value of water availability in the lower intake for 1 year is app. $30.19 \mathrm{~m}^{3} / \mathrm{sec}$ with the maximum value of app. $48.149 \mathrm{~m}^{3} / \mathrm{sec}$ and the minimum is app. $4.134 \mathrm{~m}^{3} / \mathrm{sec}$. Whereas the maximum water demand in the Lower Sausu irrigation scheme is app. $1.77 \mathrm{~m}^{3} / \mathrm{sec}$ with the minimum of $0.04 \mathrm{~m}^{3} / \mathrm{sec}$ and the average is app. $0.49 \mathrm{~m}^{3} / \mathrm{sec}$. It can be concluded that the water availability in the Sausu River Basin is sufficient to meet the water needs of the Lower Sausu Irrigation Scheme throughout the year, or there is a continuous surplus.
\end{abstract}

Keywords: dependable discharge, water availability, water needs, Sausu watershed, water balance.

\begin{abstract}
Abstrak: Studi ini bertujuan untuk mengetahui dan menganalisis ketersedian air di DAS Sausu dan kebutuhan air di D.I. Sausu Bawah. Proses penelitian diawali dengan pengumpulan data dan analisis hidro-klimatologi untuk mengetahui apakah air yang tersedia cukup atau tidak untuk digunakan selama satu periode hidrologi. Untuk mengetahui perbandingan antara kebutuhan dan ketersediaan air, maka dilakukan analisis hidro-klimatologi serta perhitungan kebutuhan air. Beberapa metode yang digunakan anatara lain adalah Metode Penman Modifikasi dan Metode F.J Mock. Metode Penman Modifikasi, digunakan untuk menghitung besarnya evapotranspirasi bulanan (ETo) dengan memperhatikan faktor-faktor klimatologi seperti suhu udara, kecepatan angin, penyinaran matahari dan kelembaban relative udara. Seterusmya, dengan menggunakan metode F.J.Mock, besarnya aliran air dari data hujan, hidrologi daerah pengaliran dan evapotranspirasi dapat dihitung. Berdasarkan hasil analisis untuk luas DAS Sausu 568,64 km², memperlihatkan bahwa nilai rerata ketersediaan air di intake bawah untuk 1 tahun adalah $30,19 \mathrm{~m}^{3} /$ detik dengan nilai maksimum $48.149 \mathrm{~m} 3 /$ det dan nilai minimum $4.134 \mathrm{~m}^{3} / \mathrm{det}_{\text {. Sedangkan kebutuhan }}$ air maksimum di D.I. Sausu Bawah adalah $1.77 \mathrm{~m}^{3} /$ detik, minimum $0.04 \mathrm{~m} 3 /$ detik dengan nilai rerata sebesar $0.49 \mathrm{~m} 3 /$ detik. Dari hasil tersebut dapat disimpulkan ketersediaan air pada DAS Sausu cukup untuk memenuhi kebutuhan air pada D.I. Sausu Bawah sepanjang tahun, atau terjadi surplus terus menerus.
\end{abstract}

Kata kunci: debit Andalan, ketersediaan air, kebutuhan air, DAS Sausu, keseimbangan air.

\section{Pendahuluan}

Neraca air merupakan suatu perbandingan antara potensi ketersediaan air dengan kebutuhan air di suatu tempat dalam periode tertentu [1-2]. Studi tentang ketersediaan dan kebutuhan air ini dimaksudkan untuk mengetahui apakah jumlah air di daerah studi surplus (kelebihan) atau mengalami defisit (kekurangan) khususnya pada bulan-bulan tertentu [3]. Dengan mengetahui kondisi surplus ataupun defisit yang ada, maka pemanfaatan dari air dapat diatur sebaik-baiknya [3-4]. Analisis evaluasi sumber daya air dapat digunakan untuk mengetahui ketersediaan sumberdaya air yang ada di suatu tempat. Analisis ketersediaan dan kebutuhan air merupakan dasar perhitungan potensi sumberdaya air di suatu wilayah [5-6]. Sebagai satuan analisisnya menggunakan luas dan bentuk lahan karena berpengaruh terhadap karakteristik dan pola pergerakan air serta hujan yang turun di suatu wilayah [7].

\section{Metode Penelitian}

\subsection{Lokasi Penelitian}

Daerah Aliran Sungai (DAS) Sausu secara administratif terletak pada Kabupaten Parigi-Moutong dan sebagian masuk dalam Kabupaten Poso (Kec.Lore Utara dan Kec. Poso Pesisir) dan luas DAS Sausu sebesar 568,64 km² (Gambar 1) [8]. Sungai Sausu menyuplai air untuk dua daerah irigasi yaitu D.I. Sausu Atas dan D.I. Sausu Bawah dengan luas total lebih dari 4000 ha. Namun demikian, dari tahun ke tahun fungsi utama DAS Sausu sebagai kawasan resapan air semakin berkurang. Hal ini disebabkan oleh berubahnya fungsi kawasan tersebut sebagai daerah resapan air menjadi lahan pertanian, sementara kawasan pertanian berubah pula menjadi areal permukiman [8]. Perubahan fungsi tersebut terjadi karena semakin tingginya tuntutan penyediaan lahan akibat semakin tingginya pertumbuhan 
penduduk yang dipicu oleh tingginya pertumbuhan ekonomi.

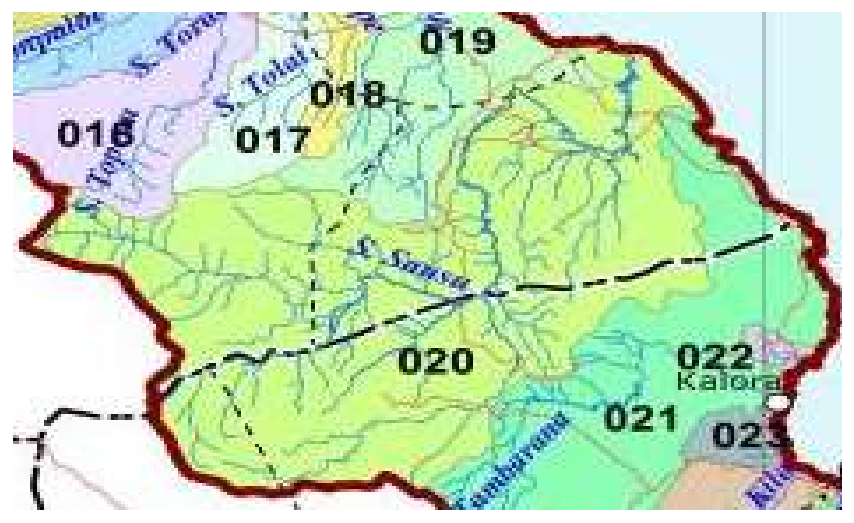

Gambar 1. Peta DAS Sausu [4]

Daerah Irigasi Sausu terbagi kepada dua bahagian yaitu Daerah Irigasi Sausu Atas dan juga Daerah Irigasi Sausu Bawah. Dalam penelitian ini hanya memperhitungkan Daerah Irigasi Sausu Bawah (Gambar 2). Daerah Irigasi Sausu Bawah terletak di Desa Sausu Alma, Kecamatan Sausu namun biasa disebut Sausu Bawah oleh warga setempat karena posisinya yang cukup rendah dari muka air laut jika dibandingkan dengan Daerah Irigasi Sausu Atas. Daerah Irigasi Sausu Bawah memiliki luas potensial sebesar 971 ha dan luas fungsional sebesar 592,63 ha. Dari luas fungsional yang ada, 580,53 ha diperuntukkan untuk tanaman padi dan selebihnya adalah palawija. Secara geografis, Daerah Irigasi Sausu terletak pada 01 ${ }^{\circ} 03^{\prime} 27^{\prime \prime}$ lintang selatan (LS) dan $120^{\circ} 25^{\prime} 12,3^{\prime \prime}$ bujur timur (BT), dimana dareah irigasi Sausu menyebar di 3 kecamatan yaitu :

1) Kecamatan Sausu

2) Kecamatan Balinggi

3) Kecamatan Torue

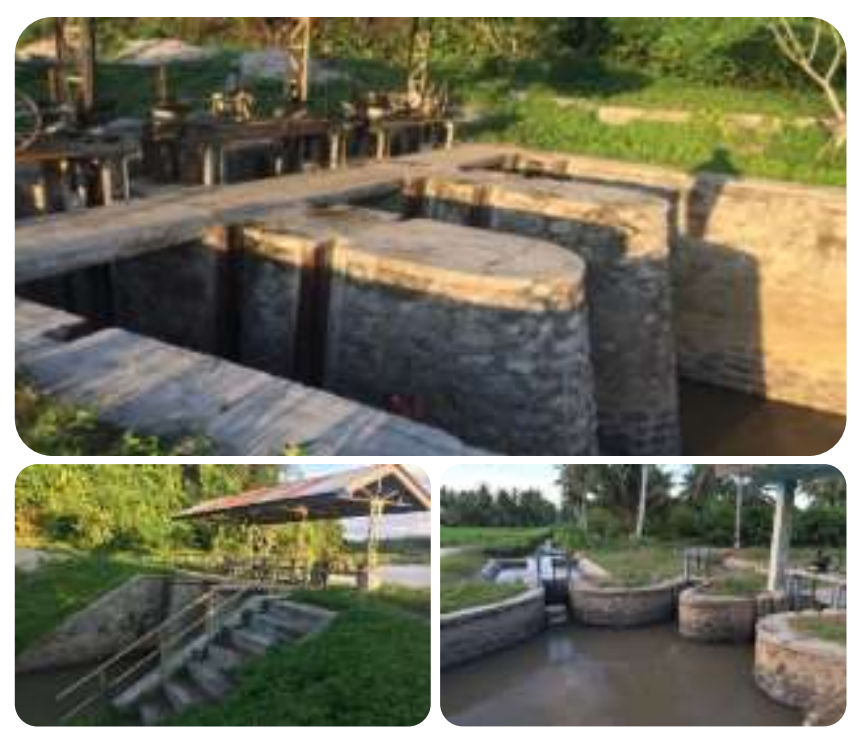

Gambar 2. Bangunan di D.I. Sausu Bawah

\subsection{Debit Sungai}

Debit sungai merupakan nilai debit yang didapatkan dengan cara melakukan pengukuran secara langsung atau menggunakan peralatan pencatat tinggi muka air otomatis. Dalam pengukuran debit secara langsung digunakan beberapa alat yang langsung dapat menujukan ketersediaan air pengairan bagi penyaluran melalui jaringan-jaringan yang telah ada atau telah dibangun. Salah satu alat dan metode yang mudah dan seringkali digunakan adalah dengan pelampung. Nilai dari debit sesaat sebagai berikut [5]:

$$
Q=A * V
$$

dimana :

$\mathrm{A}=$ Luas penampang $\left(\mathrm{m}^{2}\right)$

$\mathrm{V}=$ Kecepatan rerata $(\mathrm{m} / \mathrm{dt})$

\subsection{Curah Hujan Efektif}

Curah hujan efektif adalah curah hujan yang jatuh selama masa tumbuh tanaman, yang dapat digunakan untuk memenuhi air konsumtif tanaman. Besarnya curah hujan ditentukan dengan $70 \%$ dari curah hujan rata-rata tengah bulanan dengan kemungkinan kegagalan 20\% (curah hujan R80) [9]. Dengan menggunakan tahun dasar dengan rumus:

$$
Q 80=n / 5+1
$$

dengan $\mathrm{n}$ adalah periode lama pengamatan. Curah hujan efektif diperoleh dari $70 \%$ x R80 per periode waktu pengamatan. Apabila data hujan yang digunakan 10 harian maka persamaannya menjadi [9]:

$$
\begin{aligned}
& \text { Re padi }=(\text { R80x 70\% }) / 10 \mathrm{~mm} / \text { hari } \\
& \text { Re tebu }=(\text { R80x60\%) } / 10 \mathrm{~mm} / \text { hari }
\end{aligned}
$$

Re palawija $=(R 80 \times 50 \%) / 10 \mathrm{~mm} /$ hari

Curah hujan efektif dapat dihitung secara empiris yang dinyatakan dengan:

1) Curah hujan efektif untuk padi

$$
R e=1.0(0.82 X-30)
$$

2) Curah hujan efektif untuk palawija

$$
R e=0.75(0.82 X-30)
$$

dimana:

$\mathrm{Re}=$ Curah hujan efektif (mm/hari)

$\mathrm{X}=$ Curah hujan rata-rata bulanan ( $\mathrm{mm} / \mathrm{bulan})$

\subsection{Curah Hujan Bulanan}

Perhitungan curah hujan setengah bulanan dimaksudkan untuk menetukan jumlah hujan yang tersedia selama setengah bulan. Hal ini dilakukan karena jangka waktu penyiapan lahan akan digeser setiap 45 hari. Curah hujan setengah bulanan merupakan curah hujan andalan setiap setengah bulan dengan kemungkinan $80 \%$ atau kemungkinan tadak terpenuhi 20\% (R80) [9].

\subsection{Debit Andalan}

Debit andalan (dependable flow) adalah debit minimum sungai untuk kemungkinan terpenuhi yang sudah ditentukan yang dapat dipakai untuk irigasi. Kemungkinan terpenuhi ditetapkan $80 \%$ (kemungkinan bahwa debit sungai lebih rendah dari debit andalan adalah 20\%). Debit andalan ditentukan untuk periode tengah-bulanan. Debit minimum sungai dianalisis atas dasar data debit harian sungai agar 
analisis cukup tepat dan andal, catatan data yang diperlukan harus meliputi jangka waktu paling sedikit 10 tahun. Jika persyaratan ini tidak bisa dipenuhi, maka metode hidrologi analisis dan empiris biasa dipakai. Dalam menghitung debit andalan kita harus mempertimbangkan air yang diperlukan dari sungai hilir pengambilan. Untuk menentukan besarnya debit andalan dapat dihitung dengan metode F.J Mock.
Metode ini diperkenalkan pertama kali oleh Mock. Metode ini digunakan untuk menghitung besarnya aliran sungai dari data curah hujan, evaportranspirasi dan karateristik hidrologi daerah pengaliran. Secara keseluruhan, perhitungan debit andalan dengan Metode F.J Mock ini mengacu pada water balance, dimana volume air total yang ada di bumi adalah tetap, hanya sirkulasi dan distribusinya yang bervariasi (Gambar 3) [10-11].

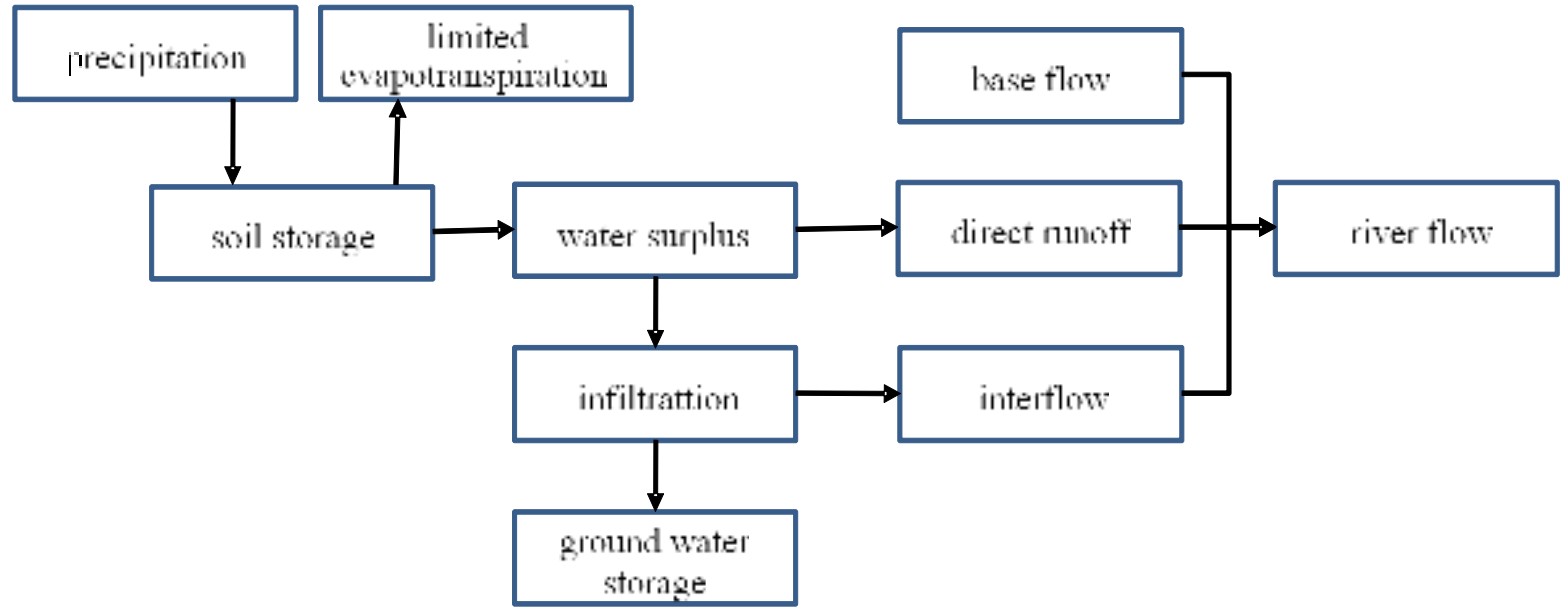

Gambar 3. Skema Simulasi Debit Metode Mock [9]. 11]:

Adapun rumus/persamaan Model F.J.Mock adalah [10-

1) Data curah hujan yang digunakan adalah curah hujan bulanan rata-rata dan jumlah dari hujan.

2) Perhitungan evapotranspirasi potensial menggunakan Metode Penman.

3) Nilai evapotranspirasi yang digunakan adalah evaportranspirasi terbatas (limitied evaportranspiration).

Hubungan antara evaportranspirasi potensional dengan evaportranspirasi aktual dihitung dengan rumus:

$E a=E T o-\Delta E$

$\Delta E=(m / 20) x(18-n)$

$\mathrm{m}=$ Faktor lahan terbuka $(\%)$ dengan kenaikan pada bulan kering dan penurunan pada bulan basah sebesar $10 \%$

$\mathrm{n}=$ Jumlah air hujan

4) Keseimbangan air di permukaan tanah

Keseimbangan air di permukaan tanah dihitung berdasarkan besarnya curah hujan bulanan dikurangi nilai evapotranspirasi terbatas rata-rata bulanan. Water Surplus (WS) adalah volume air yang akan masuk ke permukaan tanah, Air hujan yang mencapai permukaan tanah dihitung dengan rumus:

$W S=R-E a)$
Kapasitas kelembaban tanah (soil moisture capacity). Perkiraan kapasitas kelembaban tanah awal diperlukan pada saat dimulainya simulasi dan besarnya tergantung dari porositas lapisan tanah atas dari daerah pengaliran biasanya diambil (50 sampai dengan 250 ) mm, yaitu kapasitas kandungan air dalam tanah per $\mathrm{m}^{3}$.

5) Simpanan air tanah (ground water storage)

Nilai runoff dan ground water besarnya tergantung dari keseimbangan air dan kondisi tanahnya. Data yang diperlukan adalah:

- Koefisien infiltrasi ( I ) diambil 0,2 - 0,5

- Faktor resesi aliran air tanah (k) diambil 0,4 - 0,7

Besarnya volume air tanah setiap bulan dihitung dengan persamaan:

$V n=0,5(1+k) i+(k \times V(n-1))$

dimana :

$\mathrm{Vn}=$ Volume air tanah bulan ke-n,mm

$\mathrm{V}(\mathrm{n}-1)=$ Volume air tanah bulan ke-(n-1) $\mathrm{mm}$.

$\mathrm{K}=\mathrm{qt} / \mathrm{qo}=$ faktor resesi aliran air tanah.

qt $=$ Aliran tanah pada waktu $\mathrm{t}$ (bulan Ke-t).

qo $=$ Aloran air tanah pada awal (bulan Ke-0)

$\ln =$ Infiltrasi bulan ke - $\mathrm{n}$

$\Delta V n=V n-V(n-1)$

dimana :

$\Delta \mathrm{Vn}=$ Perubahan volume aliran air tanah 
Faktor resesi $\mathrm{K}$ adalah (0-1,0). Harga $\mathrm{K}$ yang tinggi akan memberikan resesi yang lambat seperti pada kondisi geologi lapisan bawah yang lolos air.

6) Aliran Sungai

Aliran=Baseflow $(\mathrm{BF})+$ Direct Runoff (DR )

dimana :

Baseflow (BF) =Infiltrasi ( I ) - perubahan volume air tanah $(\Delta \mathrm{Vn})$. Direct Runoff $(\mathrm{DR})=$ kelebihan air (WS) Infiltrasi (I). Parameter yang digunakan dalam perhitungan debit andalan:

- $\mathrm{m}=20 \%$ dengan kenaikan / penurunan dalam bulan basah / bulan kering 10\%

- Kapasitas kelembaban tanah $=200 \mathrm{~mm}$

- Koefesien infiltrasi (I) $=0,50$

- Faktor resesi aliran $(\mathrm{K})=0,70$

- Penyimpanan awal (initial storage) $=100 \mathrm{~mm}$

- Faktor limpasan badai, $\mathrm{PF}=5 \%$

\subsection{Kebutuhan Air Untuk Tanaman}

Kebutuhan air untuk tanaman adalah banyaknya air yang dibutuhkan sejak masa pengelolaan tanah, pertumbuhan tanaman sampai masa panen. Secara umum perkiraan banyaknya air yang dibutuhkan untuk tanaman pada suatu petak sawah meliputi :

- Kebutuhan air untuk masa penyiapan lahan (IR)

- Kebutuhan air untuk masa pertumbuhan (Etc)

- Kebutuhan air untuk mengganti lapisan air (WLR)

Adapun kebutuhan bersih air di sawah untuk tanaman padi (NFR) dapat dihitung dengan persmaan sebagai berikut [9]:

$N F R=E t c+P+W L R-R e$

dimana:

NFR = Kebutuhan air bersih disawah untuk padi, $\mathrm{mm} / \mathrm{hari}$

Etc $=$ Penggunaan konsumtif, $\mathrm{mm} /$ hari

$\mathrm{P}=$ Kehilangan air akibat perlokasi, $\mathrm{mm} /$ hari

$\operatorname{Re}=$ Curah hujan efektif untuk padi, $\mathrm{mm} /$ hari

$\mathrm{WLR}=$ Pergantian lapisan air selama satu atau dua bulan setelah Transpilantasi

Sedangkan banyaknya air yang dibutuhkan oleh tanaman palawijaya dapat dihitung dengan menggunakan persamaan:

$$
N F R=E t c+P-R e
$$

dimana:

Etc $=$ Penggunaan konsumtif tanaman, $\mathrm{mm} /$ hari

$\mathrm{P}=$ Perlokasi, $\mathrm{mm} / \mathrm{hari}$

$\operatorname{Re}=$ Curah hujan efektif, $\mathrm{mm} /$ hari

\subsection{Kebutuhan Air Untuk Masa Penyiapan Lahan}

Penyiapan lahan adalah pengelolahan tanah secara basah mulai dari awal dari pemberian air yang pertama, pembersihan dan sebagainya sampai sawah siap ditanami [12]. Untuk menentukan kebutuhan air selama penyiapan lahan, digunakan metode yang dikembangkan oleh Van De Goor dan Ziljstra pada tahun 1968. Metode ini didasrkan pada laju air konstan dalam litar/detik selama periode penyiapan lahan dengan persamaan sebagai berikut [9]:

$$
\mathrm{IR}=\mathrm{M} \cdot \mathrm{e}^{\mathrm{k}} 1 \mathrm{e}^{\mathrm{k}}-1
$$

dimana :

$\mathrm{IR}=$ Kebutuhan air irigasi ditingkat persawahan, $\mathrm{mm} /$ hari

$\mathrm{M}=$ Kebutuhan air untuk mengganti kehilangan akibat evapoarasi dan perlokasi di sawah yang sudah dijenuhkan

$\mathrm{M}=\mathrm{E} 0+\mathrm{P}, \mathrm{mm} /$ hari

$\mathrm{E}_{0}=$ Evaporasi air terbuka

$\mathrm{P}=$ Perlokasi, $\mathrm{mm} /$ hari

$\mathrm{K}=\mathrm{MT} / \mathrm{S}$

$\mathrm{T}=$ Jangka waktu penyiapan lahan, hari

$\mathrm{S}=$ Kebutuhan air

$\mathrm{E}=$ Bilangan eksponensial

\subsection{Kebutuhan Air Untuk Masa Pertumbuhan}

Kebutuhan air untuk pertumbuhan tanaman atau penggunan konsumtif adalah kebutuhan untuk mengganti lapisan air yang hilang akibat evapotranspirasi (Eto) dan perlokasi $(\mathrm{P})$, mulai dari bibit padi ditanam sampai padi mulai menguning.

Kebutuhan air tanaman (Etc) tergantung dari besarnya evapotranspirasi dikalikan dengan faktor koefesien tanaman kc. Dalam perhitungan transpirasi digunakan metode Penmen Modifikasi [11].

\subsection{Metode Penman Modifikasi}

Evapotranspirasi dihitung dengan menggunakan Metode Penman Modifikasi dengan memperhatikan faktorfaktor meteorologi yang terkait seperti suhu udara, kelembaban, kecepatan angin dan penyinaran matahari.

$$
E t c=k c \times E T o
$$

dimana :

$\mathrm{ETc}=$ Kebutuhan air untuk tanaman (tertentu), $\mathrm{mm} /$ hari

$\mathrm{ETo}=$ Evapotranspirasi potensial, $\mathrm{mm} /$ hari

$\mathrm{Kc}=$ Koefesien tanaman yang besarnya tergantung dari jenis, macam dan umur tanaman

Untuk mengetahui besarnya kehilangan air akibat proses penguapan, perlu dihitung evapotranspirasi. Dalam menghitung besarnya nilai evapotranspirasi,diperlukan data-data klimatologi. Berdasarkan data-data klimatologi maka nilai evapotranspirasi dapat dihitung dengan menggunakan persamaan berikut [13-15]:

$$
E T o^{*}=W \times R a+(1-W) \times f(u) \times(e s-e)
$$

dimana :

ETo* $^{*}$ Evapotranspirasi potensional, $\mathrm{mm} /$ hari

$\mathrm{W}=$ Faktor bobotan terkait suhu

$\mathrm{R}=$ Sinar bersih dalam tata uapan, dalam $\mathrm{mm} / \mathrm{hari}$

$\mathrm{f}(\mathrm{u})=$ Fungsi terkait angin

$($ es- e $)=$ Selisih antara tekanan uap jenuh pada suhu udara rerata dan tekanan uap udara yang sebenarnya.

Selanjutnya untuk mendapatkan harga evapotranspirasi harus dikalikan dengan koefesien tanaman tertentu. Dari harga evapotranspirasi yang diperoleh, kemudian digunakan untuk menghitung kebutuhan air bagi pertumbuhan dengan menyertakan data curah hujan efektif. 
2.7. Kebutuhan air untuk mengganti lapisan air (WLR)

Penggantian lapisan air di sawah dilakukan agar pada dapat tumbuh secara normal, serta mengganti lapisan air yang hilang selama transplantasi. Pergantian lapisan air dilakukan sebanyak 2 kali yaitu 1 dan 2 bulan sesudah transplantasi yang besarnya masing $3,3 \mathrm{~mm} /$ hari [9].

\subsection{Kebutuhan Air Irigasi}

Kebutuhan air irigasi adalah jumlah air yang dibutuhkan untuk mencukupi keperluan air dalam bercocok tanam pada petak sawah ditambah dengan kehilangan air yang terjadi pada jaringan irigasi [9].

a) Kebutuhan air rencana dipintu pengambilan (Intake)

Untuk menghitung kebutuhan air rencana dipintu pengambilan atau intake (DR), digunakan persamaan berikut:

$D R=N F R /($ e $x$ 8,64)

dimana :

DR = Kebutuhan rencana di pintu pengambilan, ltr/dtk/ha

NFR $=$ Kebutuhan bersih air di sawah, mm/hari

e $\quad=$ Efesiensi irigasi, $65 \%=0,65$

b) Debit kebutuhan

Debit kebutuhan adalah jumlah air yang dibutuhkan oleh irigasi tiap satuan waktu. Dalam menentukan besarnya debit kebutuhan digunakan rumus:

$Q=(N F R \times A) /(e \times 8,64 \times 1000)$

dimana :

$\mathrm{Q}=$ Debit kebutuhan $\left(\mathrm{m}^{3} / \mathrm{dtk}\right)$

NFR $=$ Kebutuhan air netto $(\mathrm{mm} /$ hari $)$

$\mathrm{A}=$ Luas areal yang akan diairi, (ha)

e $\quad=$ Efesiensi irigasi, 0.65

\subsection{Neraca Air (NA)}

Neraca air dipintu pengambilan untuk setiap periode pemberian air irigasi, dapat dihitung dengan menggunakan rumus [9]:

$N A=Q$ tersedia $-Q$ kebutuhan

dimana :

NA $\quad=$ Neraca air $\left(\mathrm{m}^{3} / \mathrm{det}\right)$

Qtersedia $=$ Debit yang diharapkan masuk ke intake $\left(\mathrm{m}^{3} / \mathrm{det}\right)$

Qkebutuhan $=$ Debit yang dibutuhkan sesuai rencana pola tanam $\left(\mathrm{m}^{3} / \mathrm{det}\right)$

\subsection{Rencana Pembagian Air}

Persamaan yang digunakan untuk menetukan besarnya nilai faktor K sebagai berikut [9]:

Faktor $K=($ Qtersedia $) /($ Qkebutuhan $)$

dimana

Jika: $\mathrm{K}>0.8$, air cukup untuk pertumbuhan tanaman. $0,60<\mathrm{K}<0,8$, air masih dianggap cukup untuk pertumbuhan tanaman. $\mathrm{K}<0,6$, kekurangan air terjadi. Dari persamaan tersebut apabila $K>1$, maka air yang tersedia lebih banyak dari air yang dibutuhkan. Sebaliknya apabila nilai $\mathrm{K}<1$, maka terjadi kekurangan air [9].

\subsection{Data Penelitian}

Untuk data-data yang akan digunakan dalam menganalisis neraca air secara keseluruhan mencangkup antara lain:

a) Data curah hujan harian

b) Data klimatologi (data temperatur udara, kecepatan angin, kelembaban udara, dan penyinaran matahari) seperti pada Gambar 4, Gambar 5 dan Gambar 6.

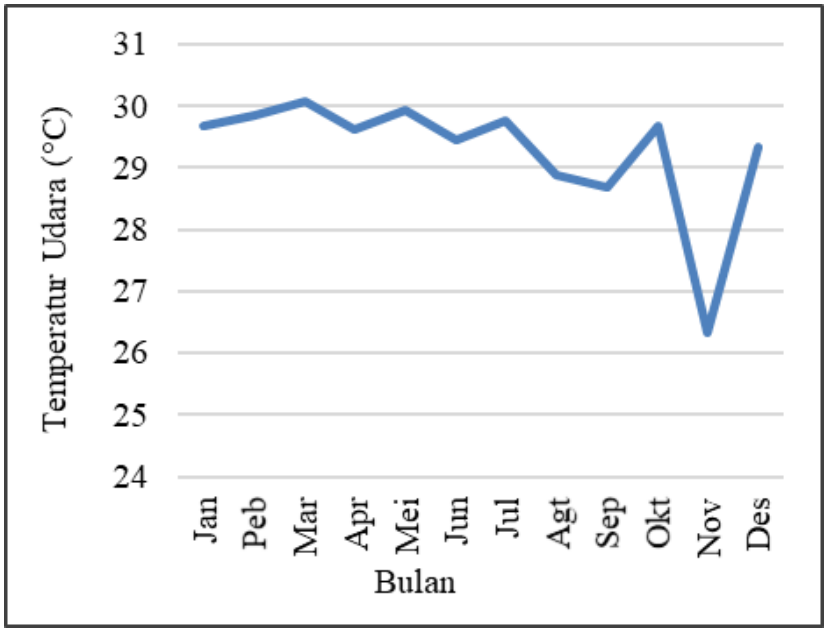

Gambar 4. Grafik temperatur udara Stasiun Tolai (20082017)

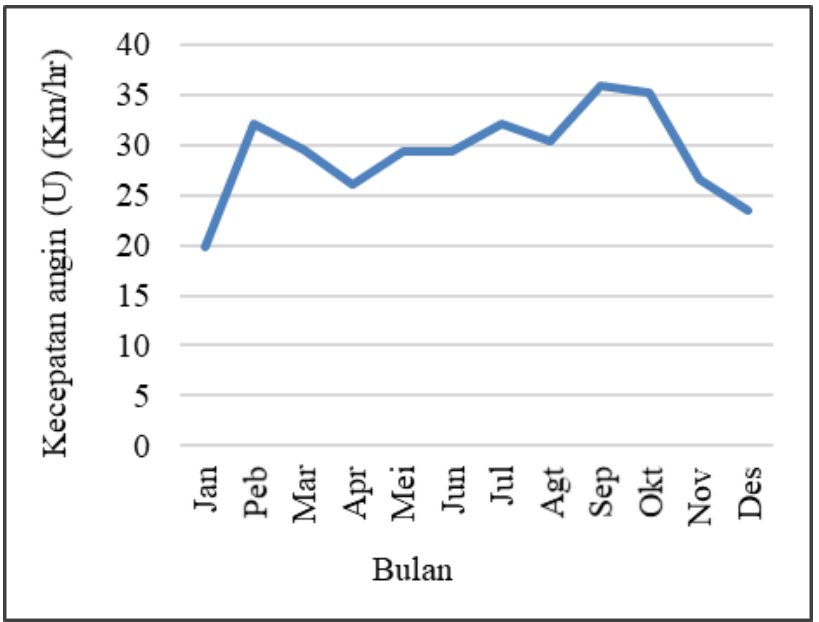

Gambar 5. Grafik kecepatan angin Stasiun Tolai (2008 2017).

\section{Hasil dan Pembahasan}

\subsection{Evapotranspirasi Potensional (ETo)}

Dalam menghitung evapotranspirasi potensional (ETo), digunakan Metode Penman Modifikasi. Dalam hal ini data temperatur, kelembaban, angin dan sinar matahari selaikuma 10 tahun terakhir menjadi parameter dalam metode tersebut. Adapun hasil perhitungan dapat dilihat pada Tabel 1 . 
Tabel 1. Perhitungan Evapotranspirasi Potensional (ETo) rata-rata 10 tahun (2008-2017) dengan Metode Penman

\begin{tabular}{|c|c|c|c|c|c|c|c|c|c|c|c|c|c|}
\hline \multirow{2}{*}{ Uratan Pertunumgan } & \multirow{2}{*}{ Ket } & \multicolumn{12}{|c|}{ Bulan } \\
\hline & & $\operatorname{Ian}$ & Peb & Mar & Agr & Mei & hin & Jul & Agt & Sep. & Okt & Nov & Des: \\
\hline Temperatur Ldara ( ${ }^{\circ} \mathrm{C}$ ) & data & 29.68 & 2986 & 30.09 & 29.62 & 2994 & 29.44 & 29.76 & 2888 & 28.68 & 2969 & 2633 & 2935 \\
\hline Kecepata angin (U) $\mathrm{Km}$ hr & data & 19.85 & 3214 & 2951 & 26.15 & 2930 & 29.44 & 3214 & 3036 & 3602 & 3530 & 26.65 & 2353 \\
\hline$f(u)=0,27(t+U / 100)$ & hatung & 0.32 & 0.36 & 0.35 & 0.34 & 0.35 & 0.35 & 036 & 0.35 & 0.37 & 0.37 & 0.34 & 033 \\
\hline Pemynaran Matahari (\%) & data & 27.70 & 30.63 & 32.02 & 31.73 & 36.49 & 34.39 & 3397 & 29.23 & 4210 & 4237 & 29.88 & 27.84 \\
\hline Kelembapan relatif, RH $(\%)$ & data & 91.33 & 90.72 & 92.74 & 91.25 & 93.93 & 93.19 & 93.39 & 93.47 & 94.43 & 91.43 & 8272 & 90.13 \\
\hline Tekanan wap jerah, ea (m bar) & tabel & 4133 & +1.71 & 42.63 & 41.53 & 42.26 & 41.11 & 41.85 & 39.82 & 39.36 & 41.69 & 3429 & 40.91 \\
\hline Tekanan uap altual,$e d=e a \times$ Rh 100 & hinme & 37.74 & 37.84 & 39.53 & 37.89 & 39.70 & 38.31 & 39.08 & $37: 22$ & 37.17 & 38.11 & 28.37 & 36.87 \\
\hline$e a-e d$ & linme & 3.58 & 3.87 & 3.09 & 3.03 & 257 & 280 & 2.77 & 2.60 & 219 & 357 & 5.93 & 4.04 \\
\hline Falter W & tabel & 0.778 & 0.779 & 0.781 & 0.778 & 0.380 & 0.377 & 0.779 & 0.734 & 0.773 & 0.778 & 0.775 & 0.777 \\
\hline$(1-W)$ & hinung & 0.22 & 0.22 & 0.22 & 0.22 & 0.22 & 0.22 & 0.22 & 0.23 & 0.23 & 0.22 & 0.23 & 0.22 \\
\hline Radiasi ekstra matahari $\mathrm{Ra}(\mathrm{mm} / \mathrm{h})$ & tabel & 15.00 & 15.50 & 15.70 & 15,30 & 14.40 & 1390 & 1410 & 14.80 & 15.30 & 15,40 & 15.10 & 1480 \\
\hline Maksinam Pesinaran matahari, $\mathrm{N}$ & tabel & 15.70 & 1570 & 15.70 & 15.70 & 1570 & 15.70 & 15.70 & 15.70 & 1570 & 15.70 & $\$ 5.70$ & 1570 \\
\hline D=N x penyinararan Matahari & himung: & 4.35 & 4.81 & 503 & 4.98 & 5.73 & 5.40 & $5.33:$ & 4.59 & 661 & 665 & 4.69 & 437 \\
\hline Rasio Keawanan nN & hinus & 0.28 & 0.31 & 0.32 & 0,32 & 0.36 & 0.34 & 0.34 & 0.29 & 0.42 & 0.42 & 0.30 & 0.28 \\
\hline Radiasi atterima matahari $R_{s}=(0,25+0,5 \mathrm{~b} N) R_{2}$ & hinus & 5.83 & 6.25 & 6.44 & 6.25 & 6.23 & 5.87 & 5.92 & 5.86 & 7.05 & 7.11 & 6.03 & 5.76 \\
\hline Rns $=(1-a) R s, a=0,25$ & hinumg & 4.37 & 4.69 & 4.83 & 4.69 & 4.67 & 4.40 & 4.44 & 4.40 & 5.28 & 533 & 4.52 & 432 \\
\hline efek Temperans,f(T) & tabel & 16.64 & 16.67 & 16.72 & 16.62 & 16.69 & 16.59 & 16.65 & 16,48 & 16.44 & 16.64 & 15.97 & 16.57 \\
\hline$F(e d)=0,34-0,04+(e d) \quad 0,5$ & hinme & 0,07 & 0.07 & 0.06 & 0.07 & 0.06 & 0.07 & 0.00 & 0.03 & 0.07 & 0.07 & 0.11 & 0.07 \\
\hline $\mathrm{f}(\mathrm{n} / \mathrm{N})=0,1+0,9 \mathrm{n} / \mathrm{N}$ & hathug & 0.35 & 0.38 & 0.39 & 0.39 & 0.43 & 0.41 & 0.41 & 0.36 & 0.48 & 0.48 & 0.37 & 0.35 \\
\hline$R n t=f(T), f(e d), f(n / N)$ & hinumg & 0,40 & 0.43 & 0.41 & 0.44 & 0.45 & 0.46 & 0.44 & 0.43 & 0.56 & 0.55 & 0.62 & 0.42 \\
\hline Energi sisa, Rn = Rus - Rni & hotung & 3.97 & 425 & 4.42 & 425 & 4.22 & 394 & 4.00 & 397 & 4.72 & 4.79 & 390 & 390 \\
\hline $\mathrm{U}(\mathrm{m} / \mathrm{des})$ & konversi & 0.23 & 037 & 0.34 & 030 & 0.34 & 0.34 & 037 & 0.35 & 0.42 & 0.41 & 0.31 & 027 \\
\hline U siang / U malam & & 1.00 & 100 & 1.00 & 1.00 & 1.00 & 1.00 & 1.00 & 1.00 & 1.00 & 100 & 100 & 1.00 \\
\hline Falktor Koreksi, C & Tabel & 1.10 & 1.10 & 100 & 0.00 & 0.50 & 0.00 & 0.50 & 1.00 & 1.10 & 1.10 & 1.10 & 1.20 \\
\hline 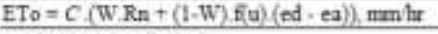 & hitumg. & 3.68 & 3.98 & 3.69 & 3.22 & 3.14 & 295 & 300 & 3.28 & 4.21 & 4.42 & 3.83 & 3.66 \\
\hline Eto koversi (mabulan) & Konversi & 11399 & 111.42 & 114.30 & 96.61 & 97.37 & 88.53 & 93.05 & 101.65 & 130.64 & 136.88 & 11481 & 113.49 \\
\hline
\end{tabular}

\subsection{Ketersediaan Air (Debit Andalan)}

Data yang menjadi parameter dalam menentukan debit andalan antara lain: data curah hujan dan data perhitungan ETo yang dihitung dengan metode Penman modifikasi. Data curah hujan yang digunakan dalam penelitian ini adalah data curah hujan bulanan yang didapatkan dari stasiun Sausu dengan pengamatan 10 tahun (2008 - 2017). Dalam menentukan ketersediaan air atau debit andalan pada DAS Sausu, perhitungan dilakukan dengan menggunakan metode F.J. Mock untuk tiap tahunnya selama 10 tahun (Gambar 7). Sedangkan untuk data perhitungan evaprotranspirasi potensial didapatkan dari hasil hitungan sebelumnya dengan menggunakan data dari stasiun Tolai dari tahun 2008- 2017.

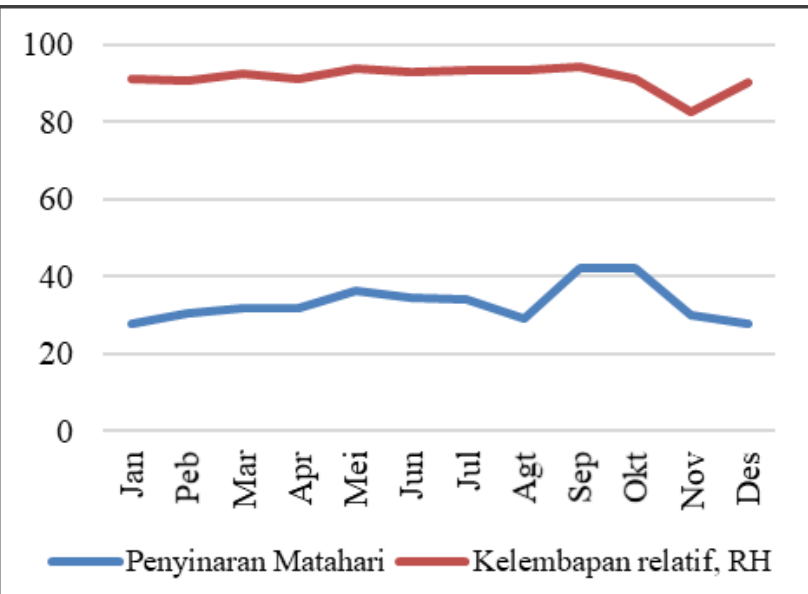

Gambar 6. Grafik penyinaran matahari dan kelembapan relatif (\%) Sta. Tolai (2008 - 2017).

Dari hasil perhitungan debit andalan setiap tahun, akan didapatkan ketersediaan air rata-rata untuk Sungai Sausu. Adapun hasil perhitungan dapat dilihat pada Tabel 2.

\subsection{Curah Hujan Efektif}

Dalam menentukan curah hujan efektif, data yang digunakan adalah data curah hujan setengah bulanan dari data stasiun curah hujan Sausu. Dalam menentukan curah hujan efektif, hendaknya memperhatikan pola tanam. Perlu diketahui, bahwa analisis ini curah hujan ditentukan dengan melihat jenis tanaman dalam satu pola tanam yang akan direncanakan.

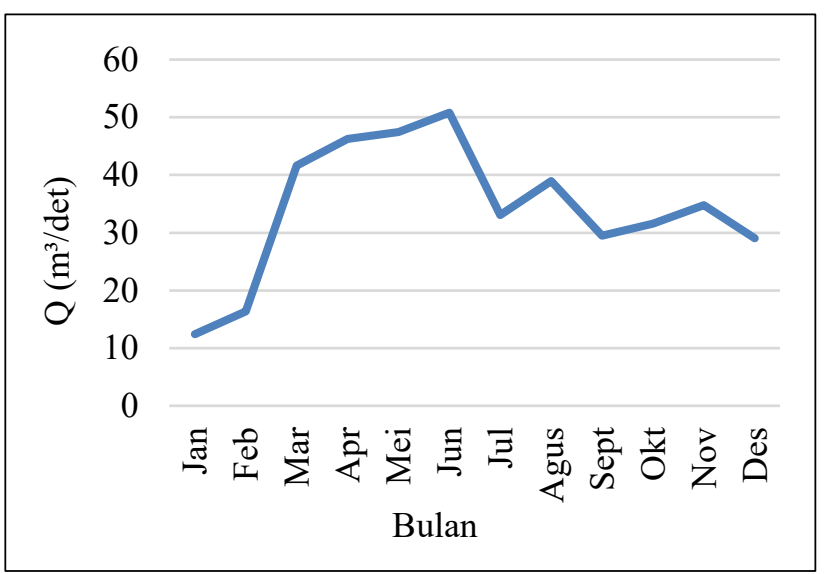

Gambar 7. Grafik debit andalan rerata (2008-2017)

Dalam menentukan curah hujan andalan tiap setengah bulan untuk tanaman Padi, dilihat dengan kemungkinan terpenuhi $80 \%$ atau kemungkinan tidak terpenuhi $20 \%$ (R80). Sedangkan untuk tanaman palawijaya diambil curah hujan bulanan dengan melihat kemungkinan $60 \%$ (R60). Adapun hasil perhitungan curah efektif untuk tanaman padi dan palawija dapat dilihat pada Tabel 3 .

\subsection{Rencana Pola Tanam}

Pola Tanam merupakan ketetapan tentang urutan jenis tanaman yang disertai jenis penanaman pada suatu 
REKOnSTRUKSI TADULAKO: Civil Engineering Journal on Research and Development, Vol. 1(2), September 2020

daerah irigasi dalam jangka waktu tertentu (satu tahun atau lebih). Dalam hal ini penulis mencoba memakai pola tanam dengan urutan jenis padi-padi-palawija. Dengan melihat debit andalan atau ketersediaan air, awal musim tanam dicoba dengan 3 alternatif, yaitu : a. Awal Bulan Oktober (tanggal 1 Oktober)

b. Pertengahan Bulan Oktober (tanggal 15 Oktober)

c. Awal Bulan November (tanggal 1 November)

Tabel 2. Rekapitulasi Debit Andalan Metode F.J. Mock ( $\left.\mathrm{m}^{3} / \mathrm{det}\right)$

\begin{tabular}{|c|c|c|c|c|c|c|c|c|c|c|c|c|}
\hline \multirow{2}{*}{ Tahun } & \multicolumn{12}{|c|}{ Bulan } \\
\hline & Jan & Feb & Mar & Apr & Mei & Jun & Jul & Agus & Sept & Okt & Nov & Des \\
\hline 2008 & 8,120 & 9,680 & 35,148 & 85,595 & 60,693 & 64,368 & 26,727 & 43,569 & 50,465 & 55,054 & 53,009 & 51,587 \\
\hline 2009 & 3,962 & 15,138 & 57,405 & 44,091 & 36,228 & 37,818 & 15,507 & 49,978 & 9,503 & 16,589 & 31,980 & 36,363 \\
\hline 2010 & 11,673 & 21,665 & 62,655 & 67,225 & 72,785 & 61,993 & 70,197 & 61,403 & 33,001 & 49,219 & 32,039 & 47,553 \\
\hline 2011 & 23,727 & 23,197 & 38,993 & 42,647 & 41,665 & 48,945 & 25,997 & 28,078 & 56,974 & 50,447 & 20,148 & 22,270 \\
\hline 2012 & 22,146 & 20,186 & 43,306 & 33,550 & 36,806 & 47,619 & 55,129 & 51,484 & 28,569 & 42,925 & 50,434 & 28,340 \\
\hline 2013 & 8,443 & 15,568 & 30,733 & 56,502 & 56,816 & 38,666 & 46,434 & 57,716 & 12,989 & 11,661 & 11,587 & 24,009 \\
\hline 2014 & 5,875 & 0,681 & 14,838 & 16,586 & 22,081 & 34,771 & 23,440 & 24,907 & 21,309 & 14,079 & 34,429 & 31,697 \\
\hline 2015 & 14,659 & 19,637 & 35,089 & 29,814 & 50,187 & 65,523 & 13,071 & 9,840 & 18,401 & 8,259 & 48,532 & 20,409 \\
\hline 2016 & 12,218 & 24,110 & 62,609 & 44,926 & 44,808 & 49,676 & $0,000 *$ & $0,000 *$ & 0,000 * & $0,000 *$ & $0,000 *$ & $0,000 *$ \\
\hline 2017 & 13,617 & 13,386 & 35,226 & 41,675 & 52,220 & 58,515 & 54,378 & 62,886 & 63,604 & 67,161 & 65,974 & 27,832 \\
\hline Rerata & 12,444 & 16,325 & 41,600 & 46,261 & 47,429 & 50,789 & 33,088 & 38,986 & 29,482 & $\mathbf{3 1 , 5 3 9}$ & 34,813 & 29,006 \\
\hline
\end{tabular}

Tabel 3. Perhitungan curah hujan efektif tanaman padi dan palawija

\begin{tabular}{|c|c|c|c|c|c|}
\hline \multicolumn{2}{|c|}{ Bulan } & $\begin{array}{c}\text { R80 } \\
\text { (Padi) }\end{array}$ & Repadi & $\begin{array}{c}\text { R60 } \\
\text { (Palawijaya) }\end{array}$ & $\mathbf{R e}_{\text {palawija }}$ \\
\hline \multirow[t]{2}{*}{ Jan } & 1 & 4,96 & 0,23 & \multirow{2}{*}{84,38} & \multirow{2}{*}{2,18} \\
\hline & 2 & 55,28 & 2,58 & & \\
\hline \multirow[t]{2}{*}{ Peb } & 1 & 23,20 & 1,08 & \multirow{2}{*}{83,14} & \multirow{2}{*}{2,15} \\
\hline & 2 & 19,20 & 0,90 & & \\
\hline \multirow[t]{2}{*}{ Mar } & 1 & 71,90 & 3,36 & \multirow{2}{*}{205,32} & \multirow{2}{*}{5,41} \\
\hline & 2 & 72,26 & 3,37 & & \\
\hline \multirow[t]{2}{*}{ Apr } & 1 & 61,96 & 2,89 & \multirow{2}{*}{209,8} & \multirow{2}{*}{5,53} \\
\hline & 2 & 77,76 & 3,63 & & \\
\hline \multirow[t]{2}{*}{ Mei } & 1 & 53,82 & 2,51 & \multirow{2}{*}{196,2} & \multirow{2}{*}{5,17} \\
\hline & 2 & 91,24 & 4,26 & & \\
\hline \multirow[t]{2}{*}{ Jun } & 1 & 84,96 & 3,96 & \multirow{2}{*}{254,1} & \multirow{2}{*}{6,71} \\
\hline & 2 & 55,30 & 2,58 & & \\
\hline \multirow[t]{2}{*}{ Jul } & 1 & 5,96 & 0,28 & \multirow{2}{*}{128,8} & \multirow{2}{*}{3,37} \\
\hline & 2 & 14,64 & 0,68 & & \\
\hline \multirow[t]{2}{*}{ Agt } & 1 & 6,76 & 0,32 & \multirow{2}{*}{115,2} & \multirow{2}{*}{3,01} \\
\hline & 2 & 9,52 & 0,44 & & \\
\hline \multirow[t]{2}{*}{ Sep } & 1 & 0,80 & 0,04 & \multirow{2}{*}{134,1} & \multirow{2}{*}{3,51} \\
\hline & 2 & 1,60 & 0,07 & & \\
\hline \multirow[t]{2}{*}{ Okt } & 1 & 0,80 & 0,04 & \multirow{2}{*}{123,9} & \multirow{2}{*}{3,24} \\
\hline & 2 & 22,96 & 1,07 & & \\
\hline \multirow[t]{2}{*}{ Nop } & 1 & 10,44 & 0,49 & \multirow{2}{*}{143,3} & \multirow{2}{*}{3,75} \\
\hline & 2 & 35,20 & 1,64 & & \\
\hline Des & 1 & 38,36 & 1,79 & 1338 & 350 \\
\hline & 2 & 39,90 & 1,86 & 155,0 & (3, \\
\hline
\end{tabular}

\subsection{Kebutuhan Air Irigasi}

Berdasarkan pola tanam Sausu Bawah yang sudah direncanakan, dilakukan perhitungan untuk mendapatkan kebutuhan air irigasi masing-masing alternatif. Seterusnya, setelah didapatkan kebutuhan air rencana untuk setiap alternative pola tanam yang sudah direncakan, dilakukan perhitungan kombinasi untuk mendapatkan kombinasi 4, 5 dan 6. Untuk lebih jelasnya, hasil perhitungan dapat dilihat pada Tabel 4.

Tabel 4. Kebutuhan air rencana masing-masing alternatif pola tanam rencana

\begin{tabular}{|c|c|c|c|c|c|c|c|}
\hline \multicolumn{2}{|c|}{ PERIODE } & \multirow{2}{*}{$\begin{array}{c}\begin{array}{c}\text { ALT } \\
1\end{array} \\
m 3 / d t \\
\end{array}$} & \multirow{2}{*}{$\begin{array}{c}\begin{array}{c}\text { ALT } \\
2\end{array} \\
m 3 / d t \\
\end{array}$} & \multirow{2}{*}{$\begin{array}{c}\text { ALT } \\
3 \\
m 3 / d t \\
\end{array}$} & \multirow{2}{*}{$\begin{array}{c}\text { ALT } \\
4 \\
m 3 / d t \\
\end{array}$} & \multirow{2}{*}{$\begin{array}{c}\text { ALT } \\
5 \\
m 3 / d t \\
\end{array}$} & \multirow{2}{*}{$\begin{array}{c}\text { ALT } \\
6 \\
m 3 / d t \\
\end{array}$} \\
\hline & & & & & & & \\
\hline \multirow[t]{2}{*}{ Okt } & 1 & 1,28 & 0,00 & 0,00 & 0,64 & 0,43 & 0,00 \\
\hline & 2 & 1,17 & 1,17 & 0,00 & 1,17 & 0,78 & 0,58 \\
\hline \multirow[t]{2}{*}{ Nop } & 1 & 0,93 & 1,18 & 1,18 & 1,06 & 1,10 & 1,18 \\
\hline & 2 & 0,81 & 0,81 & 1,06 & 0,81 & 0,89 & 0,94 \\
\hline \multirow[t]{2}{*}{ Des } & 1 & 0,76 & 0,78 & 0,78 & 0,77 & 0,77 & 0,78 \\
\hline & 2 & 0,62 & 0,75 & 0,77 & 0,68 & 0,71 & 0,76 \\
\hline \multirow[t]{2}{*}{ Jan } & 1 & 0,65 & 0,79 & 0,92 & 0,72 & 0,79 & 0,85 \\
\hline & 2 & 0,28 & 0,41 & 0,54 & 0,35 & 0,41 & 0,47 \\
\hline \multirow[t]{2}{*}{ Peb } & 1 & 1,13 & 0,44 & 0,57 & 0,79 & 0,72 & 0,51 \\
\hline & 2 & 1,15 & 1,15 & 0,46 & 1,15 & 0,92 & 0,81 \\
\hline \multirow[t]{2}{*}{ Mar } & 1 & 0,62 & 0,88 & 0,88 & 0,75 & 0,79 & 0,88 \\
\hline & 2 & 0,61 & 0,62 & 0,87 & 0,62 & 0,70 & 0,75 \\
\hline \multirow[t]{2}{*}{ Apr } & 1 & 0,59 & 0,61 & 0,62 & 0,60 & 0,61 & 0,61 \\
\hline & 2 & 0,40 & 0,52 & 0,53 & 0,46 & 0,48 & 0,53 \\
\hline \multirow[t]{2}{*}{ Mei } & 1 & 0,40 & 0,51 & 0,63 & 0,45 & 0,51 & 0,57 \\
\hline & 2 & 0,11 & 0,21 & 0,33 & 0,16 & 0,22 & 0,27 \\
\hline \multirow[t]{2}{*}{ Jun } & 1 & 0,00 & 0,14 & 0,24 & 0,07 & 0,13 & 0,19 \\
\hline & 2 & 0,00 & 0,00 & 0,28 & 0,00 & 0,09 & 0,14 \\
\hline \multirow[t]{2}{*}{ Jul } & 1 & 0,15 & 0,14 & 0,09 & 0,15 & 0,13 & 0,12 \\
\hline & 2 & 0,09 & 0,15 & 0,14 & 0,12 & 0,13 & 0,15 \\
\hline \multirow[t]{2}{*}{ Agt } & 1 & 0,04 & 0,15 & 0,22 & 0,10 & 0,14 & 0,19 \\
\hline & 2 & 0,00 & 0,04 & 0,15 & 0,02 & 0,06 & 0,10 \\
\hline \multirow[t]{2}{*}{ Sep } & 1 & 0,00 & 0,00 & 0,03 & 0,00 & 0,01 & 0,01 \\
\hline & 2 & 0,00 & 0,00 & 0,00 & 0,00 & 0,00 & 0,00 \\
\hline \multicolumn{2}{|c|}{ Jumlah } & 11,80 & 11,46 & 11,31 & 11,63 & 11,52 & 11,38 \\
\hline
\end{tabular}


Berdasarkan Tabel 4, dapat dilihat bahwa kebutuhan air rencana terbesar terdapat di alternatif 1 . Oleh karena itu, dipilih alternatif 1 dalam perhitungan neraca air.

\subsection{Neraca Air (Water Balance)}

Perhitungan neraca air (NA) pada awal musim tanam yaitu bulan Oktober dimana nilai Q kebutuhan diambil nilai pada alternatif 1 karena luas areal maksimum paling besar.
Oleh karena Daerah Irigasi Sausu Bawah terletak setelah Bendung Sausu Atas, maka untuk mendapatkan ketersedian air di intake Sausu Bawah, ketersediaan air DAS Sausu secara total harus dikurangi dahulu dengan pengambilan air di Sausu Atas. Adapun hasil perhitungan neraca air Sausu Bawah secara keseluruhan dapat dilihat pada Tabel 5.

Tabel 5. Neraca air DI. Sausu Bawah

\begin{tabular}{|c|c|c|c|c|c|c|c|c|}
\hline \multicolumn{2}{|c|}{ Bulan } & $\begin{array}{c}\text { Ketersediaan } \\
\text { air DAS } \\
\text { Sausu } \\
\left(\mathbf{m}^{3} / \text { detik }\right)\end{array}$ & $\begin{array}{c}\text { Pengambilan } \\
\text { Air Sausu } \\
\text { Atas } \\
\text { (m³/detik)* }\end{array}$ & $\begin{array}{c}\text { Ketersediaan } \\
\text { air di Intake } \\
\text { Sausu Bawah } \\
\left(\mathbf{m}^{3} / \text { detik }\right)\end{array}$ & $\begin{array}{c}\text { Kebutuhan } \\
\text { Air Sausu } \\
\text { Bawah } \\
\text { (m³/detik) }\end{array}$ & $\mathbf{K t}-\mathbf{K b}$ & $\begin{array}{c}\text { Faktor } \\
\text { K }\end{array}$ & Ket \\
\hline \multirow[t]{2}{*}{ Jan } & 1 & 12.444 & 8.31 & 4.134 & 0.65 & 3.48 & 6.34 & surplus \\
\hline & 2 & 12.444 & 5.97 & 6.474 & 0.28 & 6.19 & 22.74 & surplus \\
\hline \multirow[t]{2}{*}{ Feb } & 1 & 16.325 & 6.14 & 10.185 & 1.13 & 9.05 & 8.98 & surplus \\
\hline & 2 & 16.325 & 6.04 & 10.285 & 1.15 & 9.13 & 8.91 & surplus \\
\hline \multirow[t]{2}{*}{ Mar } & 1 & 41.600 & 3.42 & 38.180 & 0.62 & 37.56 & 61.43 & surplus \\
\hline & 2 & 41.600 & 3.09 & 38.510 & 0.61 & 37.90 & 62.79 & surplus \\
\hline \multirow[t]{2}{*}{ Apr } & 1 & 46.261 & 2.21 & 44.051 & 0.59 & 43.46 & 74.08 & surplus \\
\hline & 2 & 46.261 & 1.70 & 44.561 & 0.40 & 44.16 & 111.53 & surplus \\
\hline \multirow[t]{2}{*}{ Mei } & 1 & 47.429 & 5.91 & 41.519 & 0.40 & 41.12 & 104.87 & surplus \\
\hline & 2 & 47.429 & 2.56 & 44.869 & 0.11 & 44.76 & 411.41 & surplus \\
\hline \multirow[t]{2}{*}{ Jun } & 1 & 50.789 & 2.64 & 48.149 & 0.00 & 48.15 & - & surplus \\
\hline & 2 & 50.789 & 3.95 & 46.839 & 0.00 & 46.84 & - & surplus \\
\hline \multirow[t]{2}{*}{ Jul } & 1 & 33.088 & 4.48 & 28.608 & 0.15 & 28.46 & 188.28 & surplus \\
\hline & 2 & 33.088 & 4.60 & 28.488 & 0.09 & 28.39 & 301.95 & surplus \\
\hline \multirow[t]{2}{*}{ Agust } & 1 & 38.986 & 3.54 & 35.446 & 0.04 & 35.41 & 895.77 & surplus \\
\hline & 2 & 38.986 & 4.03 & 34.956 & 0.00 & 34.96 & - & surplus \\
\hline \multirow[t]{2}{*}{ Sept } & 1 & 29.482 & 5.08 & 24.402 & 0.00 & 24.40 & - & surplus \\
\hline & 2 & 29.482 & 6.98 & 22.502 & 0.00 & 22.50 & - & surplus \\
\hline \multirow[t]{2}{*}{ Okt } & 1 & 31.539 & 4.77 & 26.769 & 1.28 & 25.49 & 20.98 & surplus \\
\hline & 2 & 31.539 & 3.50 & 28.039 & 1.17 & 26.87 & 24.02 & surplus \\
\hline \multirow[t]{2}{*}{ Nov } & 1 & 34.813 & 3.72 & 31.093 & 0.93 & 30.16 & 33.33 & surplus \\
\hline & 2 & 34.813 & 1.51 & 33.303 & 0.81 & 32.50 & 41.35 & surplus \\
\hline \multirow[t]{2}{*}{ Dec } & 1 & 29.006 & 0.71 & 28.296 & 0.76 & 27.54 & 37.39 & surplus \\
\hline & 2 & 29.006 & 4.12 & 24.886 & 0.62 & 24.27 & 40.45 & surplus \\
\hline \multicolumn{2}{|c|}{ Jumlah } & 411.76 & 98.98 & 360.83 & 11.80 & - & - & - \\
\hline \multicolumn{2}{|c|}{ Rata-rata } & 34.31 & 4.12 & 30.19 & 0.49 & 29.70 & 129.29 & - \\
\hline
\end{tabular}

\section{Kesimpulan}

Dari hasil perhitungan ketersediaan air DAS Sausu dengan metode F.J. Mock untuk kebutuhan di D.I. Sausu Bawah dengan luas fungsional 587.73 ha, didapatkan hasil sebagai berikut: Debit maksimum $=48.149 \mathrm{~m}^{3} /$ det., debit minimum sebesar $4.134 \mathrm{~m}^{3} /$ det., dan nilai rerata sebesar $30.19 \mathrm{~m}^{3} /$ det. Sedangkan nilai kebutuhan ternyata lebih kecil dibandingkan ketersediaan sepanjang tahun, dimana kebutuhan maksimum adalah sebesar $1.77 \mathrm{~m}^{3} /$ detik dengan nilai kebutuhan rerata tahunan sebesar $0.49 \mathrm{~m}^{3} /$ detik. Ini berarti bahwa sepanjang tahun, ketersediaan air di DAS Sausu dapat memenuhi kebutuhan air untuk keperluan irigasi di D.I. Sausu Bawah (surplus air), meskipun kebutuhan air di D.I. Sausu Atas juga diperhitungkan. Bahkan ketersediaan air di lokasi studi masih memungkinkan untuk luas areal irigasi, mengubah pola tanam menjadi padi-padi-padi (untuk 3 kali tanam), dan untuk kebutuhan lainnya seperti untuk air baku.

Studi tentang ketersediaan air di DAS Sausu untuk kebutuhan air di D.I. Sausu Bawah ini tentunya masih jauh dari sempurna. Untuk itu perlu dilakukan kajian lanjutan aspek-aspek yang belum diperhitungkan di dalam studi ini, seperti kapasitas infiltrasi-perkolasi tanah, validasi hasil studi dengan data tinggi muka air sungai atau debit real time yang didapat dari stasiun AWLR, dan juga mencoba mengkaji dan membaningkan dengan metode perhitungan 
debit andalan lainnya, sehingga hasil yang didapatkan betulbetul valoid dan mendekati kondisi real di lapangan.

Ketersediaan air di daerah studi masih cukup melimpah sepanjang tahun. Mengingat bahwa daerah studi merupakan salah satu daerah lumbung pangan nasional dengan pertumbuhan penduduk cukup pesat dan salah satu penerima program transmigrasi dari Pemerintah Pusat, maka perlu untuk diadakan perencanaan jangka menengahpanjang oleh Pemerintah Kabupaten Parigi Moutong bagi pemenuhan pasokan dan jaringan air baku bagi penduduk di sekitarnya, selain program ekstensifikasi lahan pertanian yang masih memungkinkan dilaksanakan.

\section{Daftar Pustaka}

[1] D.F. Dengo, J.S.F. Sumarauw, and H. Tangkudung, "Analisis Neraca Air Sungai Ranowangko," Tekno, vol. 14, no. 65 , p. 1, 2016.

[2] C. Asdak, Hidrologi dan Pengelolaan Daerah Aliran Sungai," Yogyakarta: Gajah Mada University Press, 2002.

[3] Sekretariat Negara, Undang-Undang Nomor 17 tahun 2019 Tentang Sumber Daya Air, Jakarta: Pemerintah RI: 2019.

[4] Sekretariat Negara, Peraturan Pemerintah Republik Indonesia Nomor 37 Tahun 2012 tentang Pengelolaan Daerah Aliran Sungai, Jakarta: Pemerintah RI: 2012.

[5] E.M. Wilson, Hidrologi Teknik, Bandung: Penerbit ITB, 1993.

[6] R.K. Linsley, and J.B. Franzini, Teknik Sumber Daya Air, Jilid 2, Jakarta: Penerbit Erlangga, 1996.

[7] S. Arsyad, Konservasi Tanah dan Air, Bandung: Penerbit IPB, 2006.

[8] Direktorat Jenderal Sumber Daya Air, Peta Daerah Irigasi Sausu Kabupaten Parigi Moutong, Palu: Balai Wilayah Sungai Sulawesi III, 2015.
[9] Ditjen Sumber Daya Air, Standar Perencanaan Irigasi; Kriteria Perencanaan - Bagian Perencanaan Jaringan Irigasi, KP.01, Jakarta: Badan Penerbit Pekerjaan Umum Kementerian Pekerjaan Umum, 2011.

[10] F.J. Mock, Land Capability Apraisal Indonesia, Water Availability Apraisal, Newyork: UNDP, 1973.

[11] D. Chandrasasi, L.M Montarcih, and R.W. Wulan, "Analysis Using the F. J. Mock Method for Calculation of Water Balance in the Upper Konto SubWatershed," IOP Conference Series: Earth and Environmental Science, vol. 437, 012019, p. 1, 2020.

[12] N. Febrianti, Analisis Neraca Air DAS Sausu Untuk Kebutuhan D.I. Sausu Atas (Tugas Akhir), Palu: Jurusan Teknik Sipil Fakultas Teknik Universitas Tadulako, 2019.

[13] S.A. Nurdin, D.N. Khaeruddin, and K.F. Sulistyani, "Analisis Ketersediaan Air dengan Metode F. J. Mock di DAS Lowo Rea Kabupaten Ende untuk Kebutuhan Air Irigasi", Prosiding Seminar Nasional Teknologi Industri, Lingkungan dan Infrastruktur, vol. 1, p. 1, 2018.

[14] P.J. Osly, I. Ihsan, R.E. Ririhena, and F.D. Araswati, "Analisis Kebutuhan Dan Ketersediaan Air Kabupaten Manokwari dengan Model Mock", Jurnal Infrastruktur, vol. 5, no. 2, p. 59, 2019.

[15] W. Bunganaen, N.S. Karbeka, and E.E. Hangge, "Analisis Ketersediaan Air Terhadap Pola Tanam dan Luas Areal Irigasi Daerah Irigasi Siafu", Jurnal Teknik Sipil, vol. 9, no. 1, 2020. 
This page is intentionally left blank 